\title{
Relative importance of nanoflagellates and ciliates as consumers of bacteria in a coastal sea area dominated by oligotrichous Strombidium and Strobilidium
}

\author{
Daisuke Ichinotsuka, Hiroyuki Ueno, Shin-ichi Nakano*
}

LAFWEDY, Faculty of Agriculture, Ehime University, Tarumi 3-5-7, Matsuyama 790-8566, Ehime, Japan

\begin{abstract}
To examine the relative importance of nanoflagellates and ciliates as grazers of bacteria, we examined seasonal changes in their consumption of bacteria in a coastal sea, where the oligotrichous ciliates Strombidium and Strobilidium are dominant throughout the year. The numbers of these 2 dominant taxa accounted for 16 to $71 \%$ (average $55 \%$ ) of the total ciliate numbers. Other ciliate taxa which seasonally dominated were photosynthetic Myrionecta rubra, the aloricate oligotrichs Laboea and Lohmaniella, the loricate oligotrichs Tintinnopsis, Cyttarocylis, and scuticociliates. Fluorescently labelled $0.5 \mu \mathrm{m}$ diameter beads were used to determine grazing rates. Bacterivory was detected for nanoflagellates, Strombidium, Strobilidium, Lohmaniella, Tintinnopsis and Cyttarocylis. Ingestion rates on bacteria by nanoflagellates ranged between 0.3 and 2.2 bacteria protistan cell ${ }^{-1} \mathrm{~h}^{-1}$. Ingestion rates of the dominant ciliate taxa Strombidium and Strobilidium, when feeding on bacteria, varied from 7 to 34 bacteria protistan cell $^{-1} \mathrm{~h}^{-1}$, though the rates were low relative to those of other dominant ciliate taxa (14 to 50 bacteria protistan cell $\left.{ }^{-1} \mathrm{~h}^{-1}\right)$. Significant relationships $(\mathrm{p}<0.01)$ were found between the cell numbers of bacteria and ingestion rates of nanoflagellates, and between the cell numbers of bacteria and ingestion rates of Strombidium, whereas the relationship between the cell numbers of bacteria and ingestion rates of the total ciliates was not significant. Turnover rates of bacteria due to grazing by the total ciliates $\left(0\right.$ to $\left.0.63 \% \mathrm{~d}^{-1}\right)$ were lower than those by nanoflagellates $\left(1\right.$ to $\left.15 \% \mathrm{~d}^{-1}\right)$. Thus, it is likely that the dominant ciliates in the bay are not important grazers of bacteria, and that the main grazers of bacteria are nanoflagellates.
\end{abstract}

KEY WORDS: Microbial food web · Nanoflagellates $\cdot$ Oligotrichous ciliates $\cdot$ Grazing $\cdot$ Coastal sea $\cdot$ Japan Resale or republication not permitted without written consent of the publisher

\section{INTRODUCTION}

In pelagic marine environments, it is now commonly accepted that nanoflagellates are the most important grazers of planktonic bacteria (Caron \& Finlay 1994), and some planktonic ciliates also consume a significant portion of bacterial abundance (Rassoulzadegan et al. 1988). Fluorescently labeled surrogates (FLS) such as fluorescently labeled beads (McManus \& Fuhrman 1986) and bacteria (Sherr et al. 1987) have been widely used to determine grazing rates of protists on bacteria. The advantage of the method is that we can identify which protistan cells ingest bacteria and determine rates of grazing on bacteria for each protistan taxon.
Since elucidating the major channels for the biological transfer of organic matter within an ecosystem is one of the key issues in ecology, the FLS method is useful for identifying the dominant transfer pathways of organic matter within a microbial food web.

Consumption of bacteria by nanoflagellates and ciliates has been intensively studied in lakes by the FLS method (Sanders et al. 1989, Vaqué \& Pace 1992, Šimek et al. 1995, Nakano et al. 1998a,b), and it has been demonstrated that the relative importance of nanoflagellates and ciliates as grazers of bacteria changes seasonally in lakes (Šimek et al. 1990, 1995, Šimek \& Straskrabova 1992, Nakano et al. 1998a). In oceans and coastal seas, grazing on bacteria by nanoflagellates 
(Sherr et al. 1987, Gonzalez et al. 1990, Epstein \& Shiaris 1992, James et al. 1996) or ciliates (Albright et al. 1987, Sherr et al. 1987, 1988, 1989, Bernard \& Rassoulzadegan 1990, Gonzalez et al. 1990, Epstein \& Shiaris 1992, James et al. 1996) has also been studied using the FLS method. However, only a few studies have made comparisons between rates of grazing on bacteria by nanoflagellates and ciliates, and information on the relative importance of these groups of grazers in oceans and coastal seas is still limited (Sherr et al. 1987, Epstein \& Shiaris 1992) relative to that in freshwater.

For marine ciliates, experiments to investigate food selection have been conducted using latex beads, live food, wheat starch particles; the oligotrichous ciliates Strombidium and Strobilidium were also frequently used in such studies (Lessard \& Swift 1985, Jonsson 1986, Kivi \& Setälä 1995). These studies have demonstrated that the 2 ciliate taxa showed size-selective grazing on particles between 1 and $10 \mu \mathrm{m}$ (Jonsson 1986, Kivi \& Setälä 1995). However, <30 um ciliates are probably consumers of bacteria (Rassoulzadegan et al. 1988). Some species of Strombidium are small, and can ingest bacteria-sized particles (Rivier et al. 1985, Sherr et al. 1988). Moreover, since freshwater species of the genus Strobilidium graze on bacterial prey (Kisand \& Zingel 2000), it is likely that marine species of this genus do also. Finally, these 2 ciliate taxa often numerically dominate in many marine areas (Gonzalez et al. 1990, James et al. 1996), suggesting their importance as grazers of bacteria. However, there is a shortage of information about grazing by these 2 ciliate taxa on bacteria in a marine system. Therefore, we examined the relative importance of nanoflagellates and ciliates as grazers of bacteria by following seasonal changes in their grazing in a bay of the Uwa Sea, where Strombidium and Strobilidium are dominant throughout the year.

\section{MATERIALS AND METHODS}

This study was conducted in Uchiumi Bay, Iegushi, Uchiumi Village, Ehime Prefecture, Japan (Fig. 1). Pearl oysters Pinctada fucata are cultivated in this area, the production level of which is the highest in Japan. Oyster larvae graze on bacteria and picocyanobacteria (Tomaru et al. 2000) and, hence, studies on the ecology of the microbial food web in this area are important not only to assess food web structure and function, but also to assess fisheries management. The bay is oligo- to mesotrophic, based on its chlorophyll levels, which are usually $<2 \mu \mathrm{g} \mathrm{l}^{-1}$ (Tomaru et al. 2002). Thermal stratification in the bay usually develops from May to October.

Monthly monitoring was conducted at Stn Ub $\left(33^{\circ} 2^{\prime} \mathrm{N}, 132^{\circ} 28^{\prime} \mathrm{E}_{\text {; }}\right.$ ca. $53 \mathrm{~m}$ ) (Fig. 1), from May 2000 to July 2001. Water column temperature was measured using a Chlorotech profiler (Areck Electronics). Water samples were collected monthly from $10 \mathrm{~m}$ depth using a 6L Van-Dorn water sampler. To determine the chlorophyll a concentration, $300 \mathrm{ml}$ of the water sample was filtered through a Nuclepore filter (pore size $0.2 \mu \mathrm{m}$ ) and analyzed following the $N^{\prime} N$-dimethylformamide fluorometric method (Moran \& Porath 1980).

For enumeration of heterotrophic bacteria and nanoflagellates, $100 \mathrm{ml}$ were fixed with glutaraldehyde to a final concentration of $1 \%$; 1 to $2 \mathrm{ml}$ of the fixed water sample were for enumerating hetero-

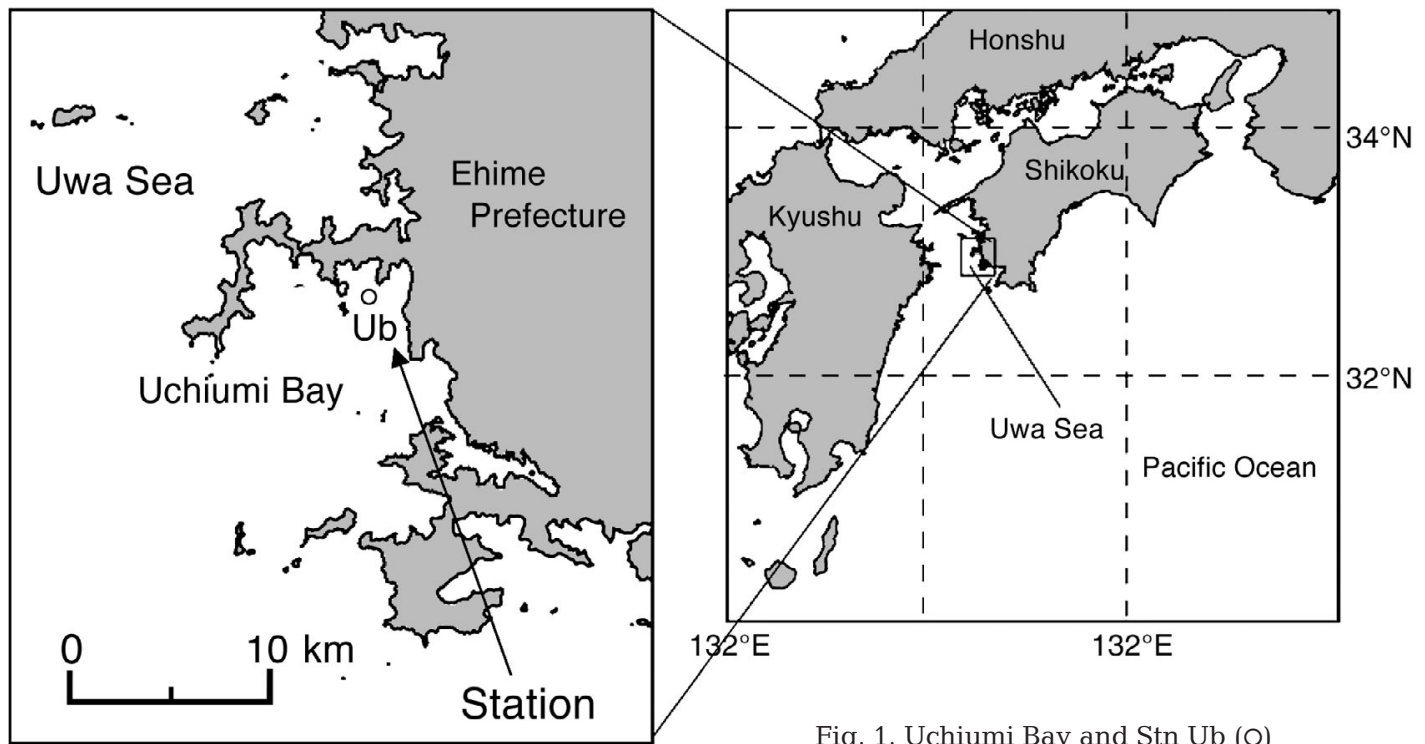

Fig. 1. Uchiumi Bay and Stn Ub (O) 

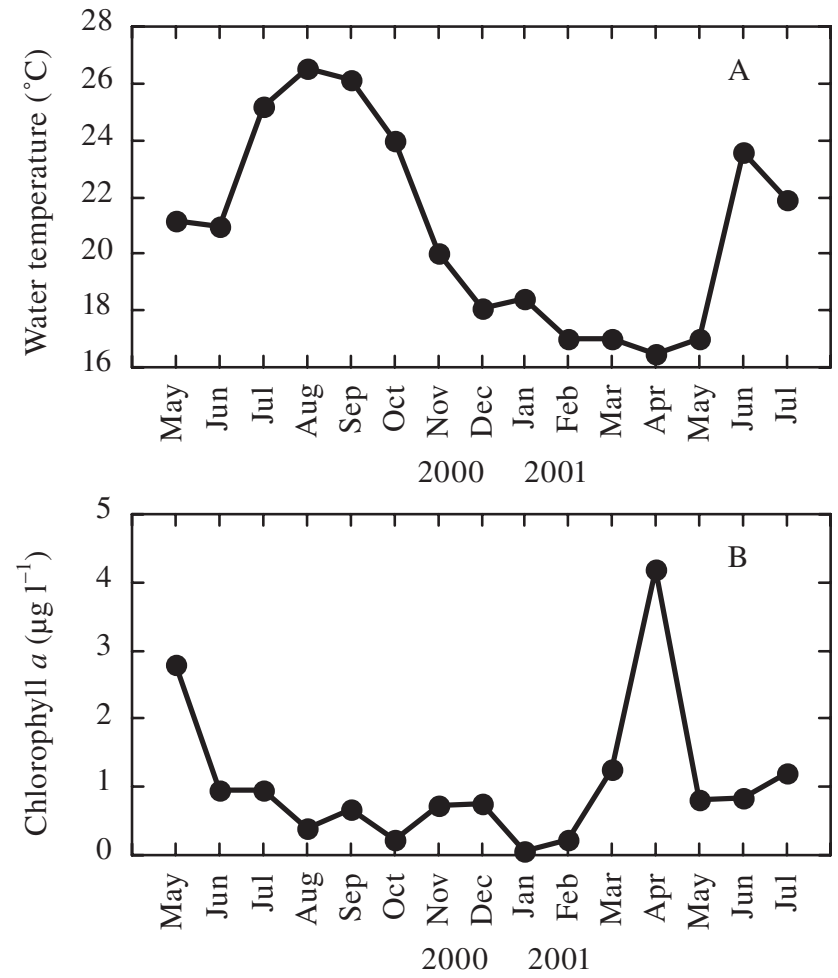

Fig. 2. Seasonal changes in (A) water temperature and (B) chlorophyll a concentration at Stn Ub

trophic bacteria and 30 to $50 \mathrm{ml}$ were for enumerating nanoflagellates. Both were counted using an epifluorescence microscope under ultraviolet excitation by the DAPI (Porter \& Feig 1980) and primulin (Caron 1983) methods, using black-stained 0.2 and $0.8 \mu \mathrm{m}$ Nuclepore filters, respectively. We did not discriminate flagellates into autotrophic and heterotrophic groups; hence, cells $<20 \mu \mathrm{m}$ with flagellae were all counted as nanoflagellates and considered potential bacterivores. At least 300 cells of heterotrophic bacteria and 30 nanoflagellate cells were counted in each sample: the CVs of the counts were respectively 12 and $19 \%$.

For enumeration of ciliates, a $500 \mathrm{ml}$ portion of the water sample was fixed with acid Lugol's solution to a final concentration of $1 \%$, and the ciliates were concentrated by sedimentation. Ciliate cells were enumerated in a haematocytometer at $200 \times$ or $400 \times$ magnification. We identified ciliate taxa using the classification guides of Foissner (1994), Chihara \& Murano (1997), Strüder-Kypke \& Montagnes (2002) and Strüder-Kypke et al. (2002).

Grazing rates of nanoflagellates and ciliates feeding on bacteria were determined using $0.5 \mu \mathrm{m}$ fluorescently labeled beads (FLB; fluoresbrite yellow green microspheres, Polysciences) following the methods of McManus \& Fuhrman (1986). For this, $250 \mathrm{ml}$ water samples were poured into triplicate polycarbonate bottles and FLB were added to each bottle $\left(0.5 \times 10^{5}\right.$ FLB ml $\mathrm{m}^{-1}$ to $1.0 \times 10^{5} \mathrm{FLB} \mathrm{ml}^{-1}$ ) at $<10 \%$ of the in situ bacterial cell numbers (McManus \& Okubo 1991). The FLB-spiked samples were then incubated for 15 min at the original depth at which the water sample had been collected. Note preliminary experiments indicated ingestion of FLB by nanoflagellates and ciliates was saturated after 20 and $40 \mathrm{~min}$, respectively (data not shown). After the incubation, subsamples were taken and fixed with $4 \%$ ice-cold, buffered glutaraldehyde, an effective fixative to reduce the egestion of bacteria which have been taken into a food vacuole of nanoflagellates and ciliates (Sanders et al. 1989). To account for any FLB adsorbed to cell surfaces of the protists, a time-zero control was taken and fixed as described above. Nanoflagellates and ciliates thus fixed were, respectively, retained on 0.8 and $5 \mu \mathrm{m}$ black Nuclepore filters and stained with primulin, as previously described. The FLB in their food vacuoles were then counted under an epifluorescence microscope. At least 100 nanoflagellate cells and 20 to 40 ciliate cells were examined from each sample. Daily ingestion rates were then determined assuming no biases for FLBs and a constant grazing rate over $24 \mathrm{~h}$. Bacterial turnover rates $\left(\% \mathrm{~d}^{-1}\right)$ were estimated by expressing the bacteria ingested by the nanoflagellates or ciliates as percentages of the corresponding bacterial cell numbers, with the assumption that the bacterial cell numbers remained at steady-state.

\section{RESULTS}

The water temperature at $10 \mathrm{~m}$ depth in Uchiumi Bay rapidly increased from July $\left(25.2^{\circ} \mathrm{C}\right)$ to August $2000\left(26.5^{\circ} \mathrm{C}\right)$, decreased from September $\left(26.1^{\circ} \mathrm{C}\right)$ to April $2002\left(16.5^{\circ} \mathrm{C}\right)$ and increased again from May 2002 (Fig. 2A). Thermal stratification developed from May to October. Chlorophyll a concentrations decreased from June $2000\left(0.95 \mu \mathrm{g} \mathrm{l}^{-1}\right)$ to

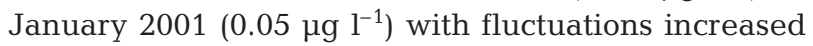
to a maximum in April $2001\left(4.20 \mu \mathrm{g} \mathrm{l}^{-1}\right)$ and decreased again from May 2001 (Fig. 2B).

Bacterial cell numbers (Fig. 3A) decreased from June $2000\left(1.4 \times 10^{6}\right.$ cells $\left.\mathrm{ml}^{-1}\right)$ to February 2001 $\left(0.6 \times 10^{6}\right.$ cells ml $\left.{ }^{-1}\right)$, increased from March $\left(1.2 \times 10^{6}\right.$ cells $\left.\mathrm{ml}^{-1}\right)$, attained a maximum in May $\left(1.7 \times 10^{6}\right.$ cells $\left.\mathrm{ml}^{-1}\right)$ and then gradually decreased to July $\left(1.4 \times 10^{6}\right.$ cells $\mathrm{ml}^{-1}$ ) (Fig. 2A). Nanoflagellate densities (Fig. 3B) ranged between 770 cells $\mathrm{ml}^{-1}$ (January 2002) and 4300 cells $\mathrm{ml}^{-1}$ (August 2001), and high densities tended to be recorded during the stratified period (May to August). There were large fluctuations in the ciliate numbers, varying from 1.2 (December 2001) 

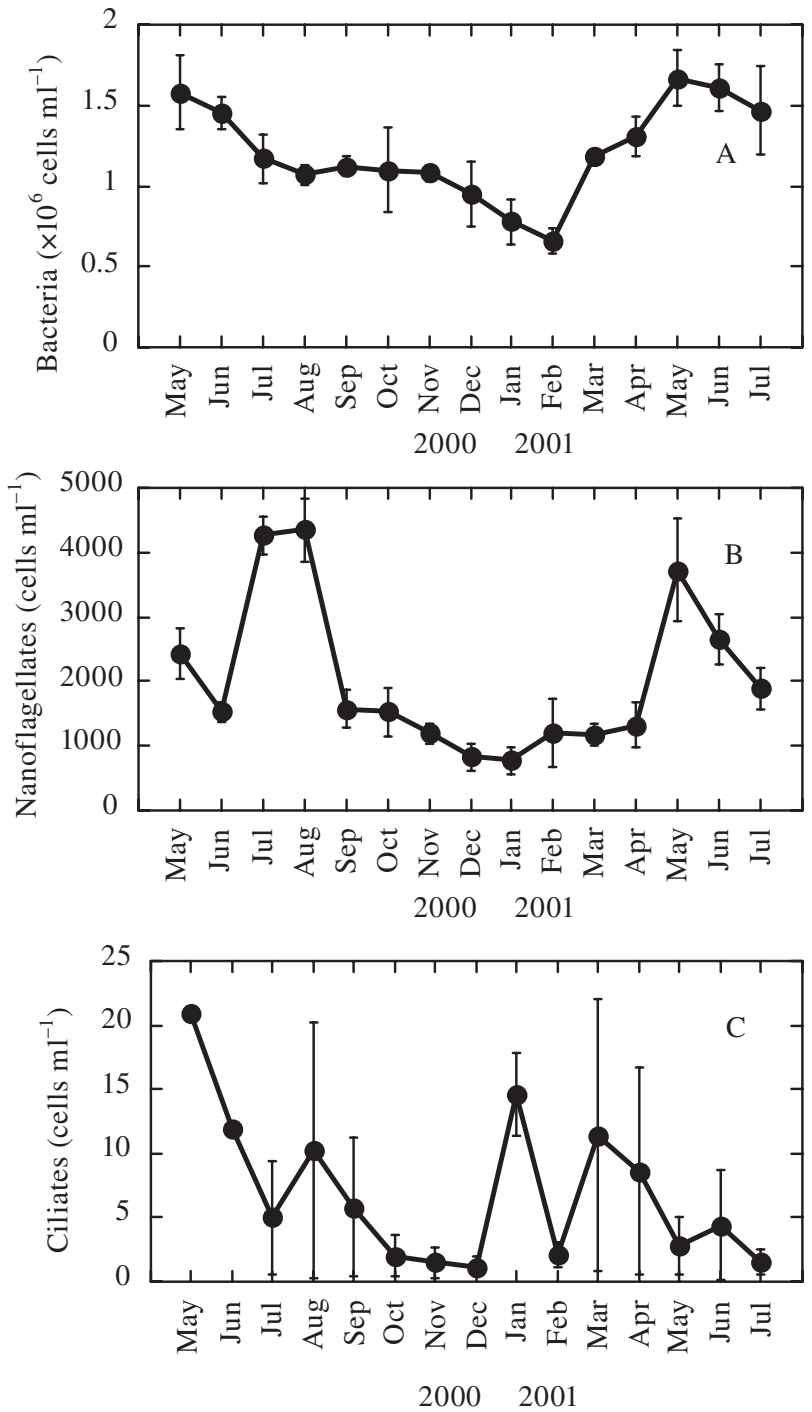

Fig. 3. Seasonal changes in cell numbers (mean \pm SD) of (A) bacteria, (B) nanoflagellates and (C) ciliates at Stn Ub

to 21 (January 2002) cells $\mathrm{ml}^{-1}$ (Fig. 3C). The dominant taxa were the oligotrichous genera Strombidium (dominated by $S$. conicum, $S$. epideum, S. lynni, S. emergens, $S$. wuffi and $S$. dalum) and Strobilidium (dominated by $S$. neptuni and S. spiralis) (Fig. 4). The numbers of these 2 dominant taxa accounted for 16 to $71 \%$ (average $55 \%$ ) of the total ciliate numbers. The photosynthetic Myrionecta rubra (Gymnostomatida) was detected throughout the study period, dominating between December 2000 and February 2001 (Fig. 4). The aloricate oligotrichs Laboea and Lohmaniella, loricate oligotrichs Tintinnopsis and Cyttarocylis and Scuticociliates were also seasonally abundant (Fig. 4), although their abundance was still low relative to Strombidium and Strobilidium.
Table 1. Ingestion rates on bacteria by some ciliate taxa dominated in the present study

\begin{tabular}{|lcrr|}
\hline & $\begin{array}{c}\text { Average ingestion rate } \\
\text { (bacteria protistan cell }{ }^{-1} \mathrm{~h}^{-1} \text { ) }\end{array}$ & Range & $\mathrm{n}$ \\
\hline Codonella & 29 & $14-44$ & 30 \\
Cyttarocylis & 42 & $27-76$ & 45 \\
Lohmaniella & 39 & 39 & 3 \\
Strobilidium & 23 & $7-34$ & 102 \\
Strombidium & 18 & $7-34$ & 342 \\
Tintinnopsis & 47 & $43-50$ & 20 \\
\hline
\end{tabular}

Ingestion rates of nanoflagellates ranged between 0.3 and 2.2 bacteria protistan cell ${ }^{-1} \mathrm{~h}^{-1}$, decreasing from May to December and increasing from January 2001 onwards (Fig. 5A). Changes in the ingestion rates of the total ciliates (Fig. 5B) did not show any clear seasonal trend, and the maximum rate (31 bacteria protistan cell $^{-1} \mathrm{~h}^{-1}$ ) was found in May 2002 (Fig. 5B). Ingestion rates of the dominant ciliate taxa Strombidium spp. and Strobilidium spp. varied within the same range from 7 to 34 bacteria protistan cell ${ }^{-1} \mathrm{~h}^{-1}$ (Table 1), which were lower than those of other ciliate taxa (Table 1).

A significant correlation $(\mathrm{n}=14, \mathrm{r}=0.826, \mathrm{p}<0.01)$ occurred between bacterial cell numbers and nanoflagellate ingestion rates (Fig. 6A). There was no significant correlation between cell numbers of bacteria and ingestion rates of ciliates (Fig. 6B). However, there was a significant correlation $(n=13, r=0.757, p<0.01)$ between cell numbers of bacteria and ingestion rates of Strombidium (Fig. 6C), while no significant correlation occurred between cell numbers of bacteria and ingestion rates of other individual ciliate taxa.

Daily consumption of bacteria by nanoflagellates varied from $0.06 \times 10^{5}$ ingested bacterial cells ml ${ }^{-1} \mathrm{~d}^{-1}$ (December 2000) to $1.6 \times 10^{5}$ bacteria $\mathrm{ml}^{-1} \mathrm{~d}^{-1}$ (May 2001). Bacterial turnover rates $\left(\% \mathrm{~d}^{-1}\right)$, due to grazing by nanoflagellates, were determined as between 1 and $15 \% \mathrm{~d}^{-1}$ (Fig. 7A), tending to be higher during the stratified period. Daily consumption of bacteria by ciliates was lower than that of nanoflagellates (310 to 7500 bacteria $\mathrm{ml}^{-1} \mathrm{~d}^{-1}$ ), and bacterial turnover rates due to the total ciliates were estimated to be 0 to $0.63 \% \mathrm{~d}^{-1}$ (Fig. 7B). The turnover rates due to ciliate grazing had no clear seasonal trend (Fig. 7B).

\section{DISCUSSION}

In the original concept of microbial loop (Azam et al. 1983), both nanoflagellates and ciliates consume a portion of bacterial abundance. Successive microbiological studies in marine environments have supported the concept, though the importance of nano- 


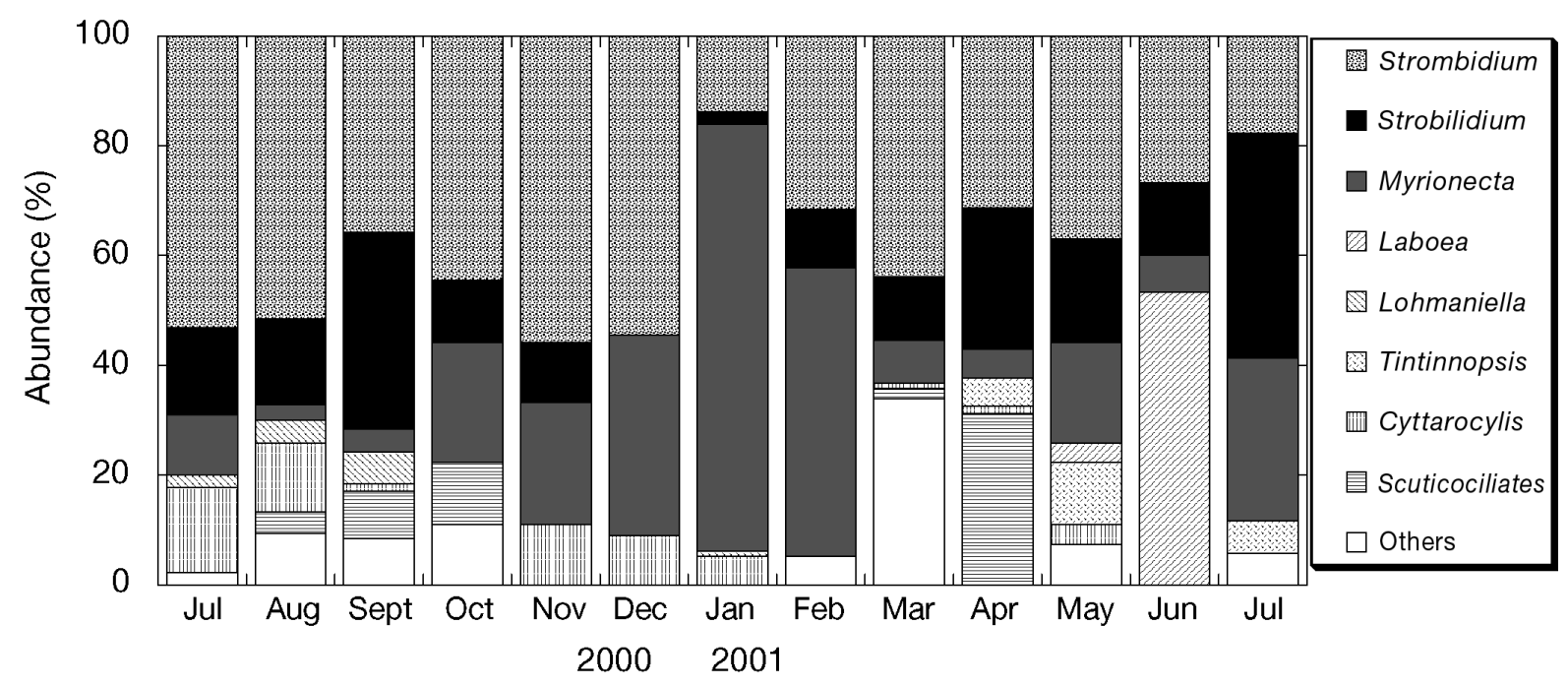

Fig. 4. Seasonal changes in abundance (\%) of dominant ciliate taxa at Stn Ub

flagellates as grazers of planktonic bacteria tends to be higher than that of ciliates (Rassoulzadegan et al. 1988, Caron \& Finlay 1994). Thus, there may be competition between nanoflagellates and ciliates for bacterial food, but the partitioning of bacterial food between nanoflagellates and ciliates is still poorly understood. In the present study, we did find a significant functional response between cell numbers of bacteria and inges-

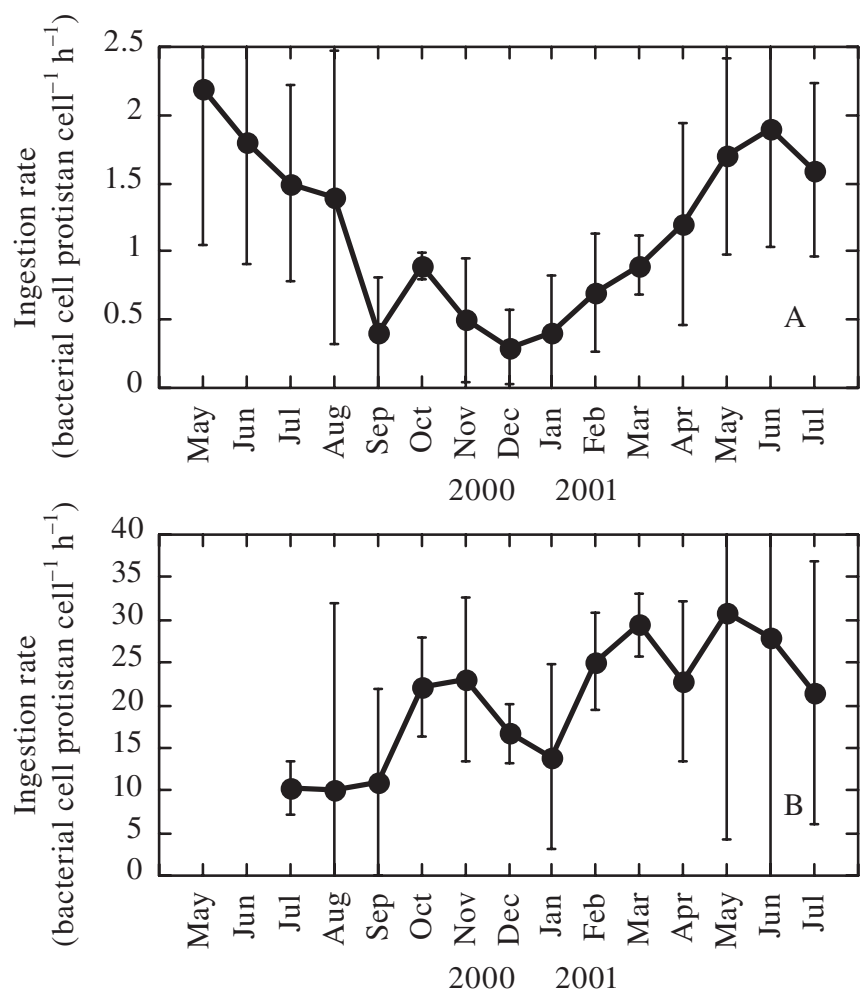

Fig. 5. Seasonal changes in ingestion rates (mean $\pm \mathrm{SD}$ ) of bacteria by (A) nanoflagellates and (B) ciliates at Stn Ub tion rates of nanoflagellates (Fig. 6A). This relationship indicates subsaturation of grazing on bacteria by flagellates. Thus, the rate at which nanoflagellates graze on bacteria in Uchiumi Bay is limited by bacterial cell numbers. By contrast, we did not find a significant functional response between cell numbers of bacteria and ingestion rates of ciliates (Fig. 6B). Usually, ciliates consist of diverse species with various feeding modes which allow grazing on variety of food items. We also found seasonal changes in composition of dominant ciliate taxa during the study period in Uchiumi Bay (Fig. 4). Hence, it is probably inappropriate to treat whole ciliate community as grazers of bacteria. Indeed, we detected significant correlation between cell numbers of bacteria and ingestion rate of Strombidium (Fig. 6C).

We used artificial fluorescent beads to determine protistan grazing rate on bacteria (see 'Materials and methods'). Heat-killed and fluorescently stained minicell producing bacteria were used in our previous studies (Nakano 1994, Nakano et al. 1998a,b), but no general pattern of preference has been found for either heatkilled bacteria or artificial beads (Sanders et al. 1989, Montagnes \& Lessard 1999). However, previous studies have demonstrated preference on prey types, living or non-living, by protists (Landry et al. 1991, Montagnes \& Lessard 1999), and thus the methods using fluorescent surrogates to determine grazing rates by protists have limitations (Vaqué et al. 1994, Strom 2000). Hence, grazing rates in the present study may be underestimated due to the use of artificial beads as surrogates.

On an individual basis, ciliates may graze more bacterial cells than nanoflagellates do (Table 1, Figs. $5 \& 6$ ). However, abundance of ciliates is usually less than that of nanoflagellates in marine environments (Carlough \& Meyer 1989, James et al. 1996), and 
Table 2. Turnover rates of bacteria due to protistan grazing $\left(\% \mathrm{~d}^{-1}\right)$, from the literature

\begin{tabular}{|c|c|c|c|c|c|}
\hline & Trophic state & Protists & Range & Average & Source \\
\hline \multicolumn{6}{|l|}{ Marine } \\
\hline $\begin{array}{l}\text { Hudson Estuary, } \\
\text { USA }\end{array}$ & & $\begin{array}{l}\text { Flagellates } \\
\text { and ciliates }\end{array}$ & $3-16$ & 10 & Vaqué et al. (1992) \\
\hline $\begin{array}{l}\text { Off South Island, } \\
\text { New Zealand }\end{array}$ & & $\begin{array}{l}\text { Flagellates } \\
\text { and ciliates }\end{array}$ & $0.2-2.3$ & & James et al. (1996) \\
\hline $\begin{array}{l}\text { Sapelo Island } \\
\text { tidal creek, USA }\end{array}$ & & Flagellates & & 15 & Sherr et al. (1987) \\
\hline $\begin{array}{l}\text { Sapelo Island } \\
\text { tidal creek, USA }\end{array}$ & & Ciliates & & 90 & Sherr et al. (1987) \\
\hline $\begin{array}{l}\text { Savin Hill } \\
\text { Cove embayment, USA }\end{array}$ & Eutrophic & Flagellates & & 10 & Epstein \& Shiaris (1992) \\
\hline $\begin{array}{l}\text { Savin Hill } \\
\text { Cove embayment, USA }\end{array}$ & Eutrophic & Ciliates & & 6 & Epstein \& Shiaris (1992) \\
\hline $\begin{array}{l}\text { Uchiumi Bay, } \\
\text { Japan }\end{array}$ & $\begin{array}{l}\text { Oligo- to } \\
\text { mesotrophic }\end{array}$ & Flagellates & $1-15$ & 5.5 & This study \\
\hline $\begin{array}{l}\text { Uchiumi Bay, } \\
\text { Japan }\end{array}$ & $\begin{array}{l}\text { Oligo- to } \\
\text { mesotrophic }\end{array}$ & Ciliates & $0.05-0.65$ & 0.1 & This study \\
\hline \multicolumn{6}{|l|}{ Freshwater } \\
\hline $\begin{array}{l}\text { Furuike Pond, } \\
\text { Japan }\end{array}$ & Hypereutrophic & $\begin{array}{l}\text { Flagellates } \\
\text { and ciliates }\end{array}$ & $5-112$ & 25 & Nakano et al. (1998a) \\
\hline $\begin{array}{l}\text { Grosser Binnensee, } \\
\text { Germany }\end{array}$ & Eutrophic & Flagellates & $1-89$ & & Jürgens \& Stolpe (1995) \\
\hline $\begin{array}{l}\text { Lake Biwa (North Basin), } \\
\text { Japan }\end{array}$ & Mesotrophic & Flagellates & $0.6-16$ & 3.5 & Nakano (1994) \\
\hline $\begin{array}{l}\text { Lake Biwa (South Basin), } \\
\text { Japan }\end{array}$ & Eutrophic & Flagellates & $1.3-23$ & 7.7 & Nakano (1994) \\
\hline $\begin{array}{l}\text { Lake Biwa (North Basin), } \\
\text { Japan }\end{array}$ & Mesotrophic & Flagellates & $0.7-24$ & 5.9 & Nakano et al. (1998b) \\
\hline $\begin{array}{l}\text { Lake Oglethorpe, } \\
\text { USA }\end{array}$ & Eutrophic & Flagellates & $3-35$ & 12 & Sanders et al. (1989) \\
\hline $\begin{array}{l}\text { Ogeechee River, } \\
\text { USA }\end{array}$ & Dystrophic & Flagellates & $0.2-59$ & 15 & Carlough \& Meyer (1991) \\
\hline $\begin{array}{l}\text { Ogeechee River, } \\
\text { USA }\end{array}$ & Dystrophic & Ciliates & $0.0044-3.5$ & 0.58 & Carlough \& Meyer (1991) \\
\hline $\begin{array}{l}\text { Paul Lake, } \\
\text { USA }\end{array}$ & Oligotrophic & Flagellates & $0.8-2.3$ & 1.3 & Vaqué \& Pace (1992) \\
\hline $\begin{array}{l}\text { Plusssee, } \\
\text { Germany }\end{array}$ & Eutrophic & Flagellates & & 33 & Fukami et al. (1991) \\
\hline $\begin{array}{l}\text { Tuesday Lake, } \\
\text { USA }\end{array}$ & Oligotrophic & Flagellates & $0.2-5.9$ & 3.5 & Vaqué \& Pace (1992) \\
\hline
\end{tabular}

therefore grazing pressure on bacteria by ciliates would be lower than that by nanoflagellates. In the present study, consumption of bacteria due to grazing by ciliates was negligible relative to that by nanoflagellates (Fig. 7, Table 2), and this was due to low abundance of ciliates (Fig. 3).

Small ciliates, whose cell sizes are less than $30 \mu \mathrm{m}$, are probably consumers of bacteria (Rivier et al. 1985, Rassoulzadegan et al. 1988, Sherr et al. 1988), though larger ciliates may incidentally graze on bacteria. In the present study, some of the dominant ciliate species were small $(<30 \mu \mathrm{m})$ - Strombidium epideum,
S. emergens, and $S$. dalum-and they may prey on bacteria since other small Strombidium species, such as $S$. sulcatum, which is now recognized as $S$. inclinatum (Montagnes et al. 1990, Granda \& Montagnes 2003), are known to do so (Sherr et al. 1988), although the main foods of our 3 dominant ciliates are currently unknown (Strüder-Kypke et al. 2002). We found a significant correlation between cell numbers of bacteria and ingestion rate of Strombidium (Fig. 6C). However, previous studies using other types of surrogates such as latex beads (Jonsson 1986) and wheat starch (Kivi \& Setälä 1995) have demonstrated that the 

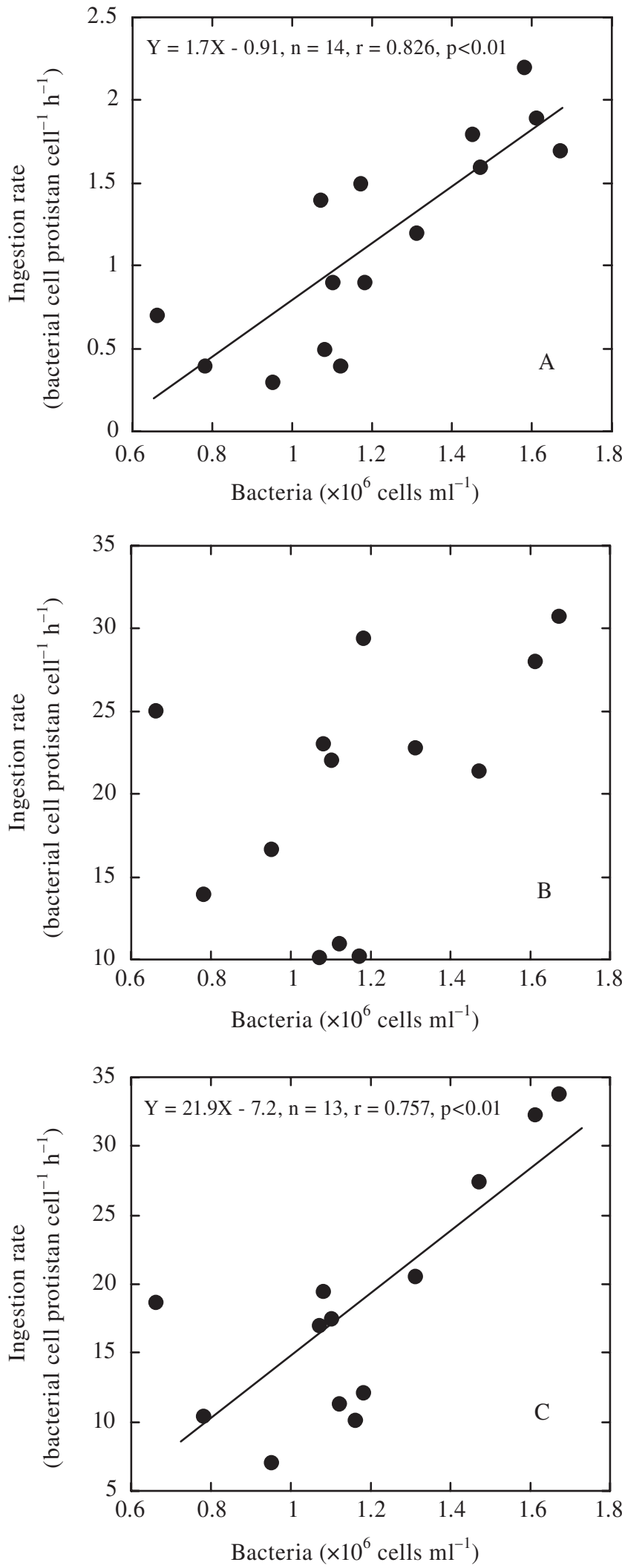

Fig. 6. Relationships between cell numbers of bacteria and ingestion rate of (A) nanoflagellates, (B) ciliates, and (C) Strombidium
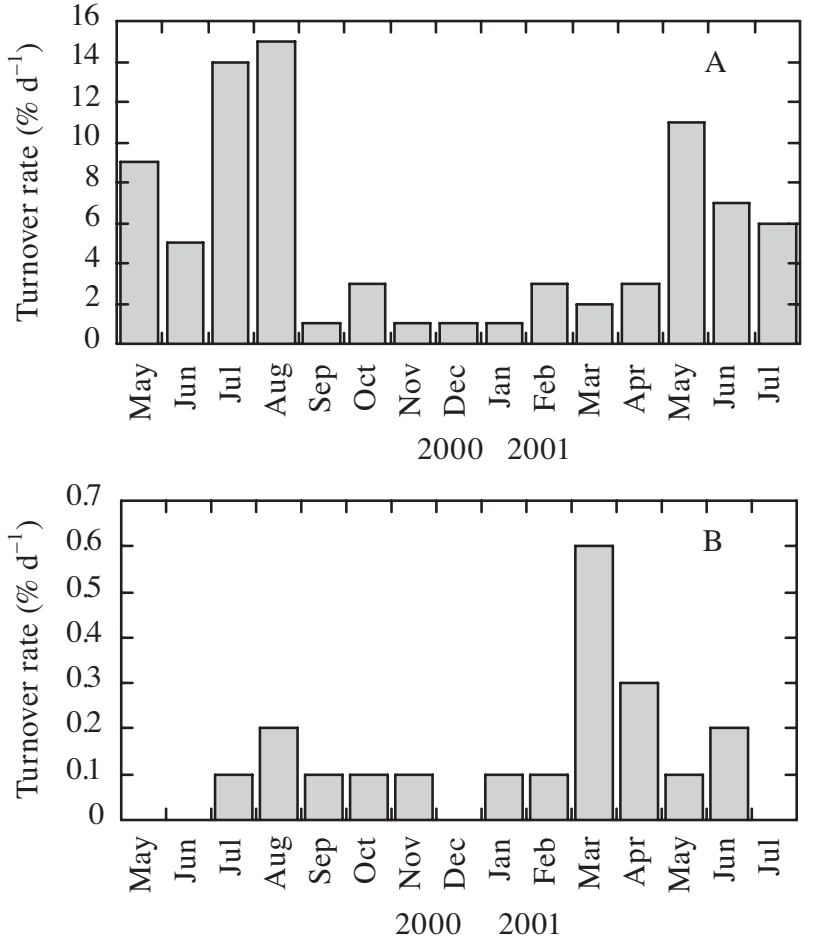

Fig. 7. Seasonal changes in turnover rates of bacteria due to grazing by (A) nanoflagellates and (B) ciliates at Stn Ub

marine ciliate taxa studied so far showed a preference for feeding on particles with a variety of sizes and could not effectively retain particles less than $2 \mu \mathrm{m}$. Most of the isolates of Strombidium and Strobilidium examined so far also could not effectively ingest particles less than $2 \mu \mathrm{m}$ (Fenchel 1980, Jonsson 1986). In the present study, ingestion rates on bacteria of Strombidium and Strobilidium were low relative to those of other ciliate taxa such as Cyttarocylis, Lohmaniella and Tintinnopsis (Table 1), though there was a significant correlation between bacterial abundance and Strombidium ingestion rate (Fig. 6C). It is, therefore, likely that the FLB $(0.5 \mu \mathrm{m})$ that we used for determination of grazing rates were edible, but inappropriately small, for ingestion by the Strombidium and Strobilidium examined in the present study.

Cell number of bacteria increased near the time of the spring bloom of phytoplankton and remained high in the summer (Figs. 2B \& 3A), possibly due to an increased release of dissolved organic matter from phytoplankton in the spring and to the recycling of organic matter in the summer. There was a commensurate increase in cell number of nanoflagellates and in their grazing rate (Figs. 3B \& 5A), resulting in an increase of their grazing pressure (Fig. 7A). Although there was also an increase in grazing pressure on bacteria by ciliates in the spring, this remained low (Fig. 7B). Probably, the ciliates that dominated in the present study mainly 
ingested prey larger than bacteria as small nanoflagellates (2.2 to $5 \mu \mathrm{m})$ (Lynn \& Montagnes 1991). In our previous study, conducted in a hypereutrophic freshwater environment (Nakano et al. 2001), we found that the most important predators for nanofalgellates were ciliates, and that predation by ciliates accounted for about $80 \%$ of nanoflagellate production. Low abundance of nanoflagellates between September and April (Fig. 3B) might be explained by predation on nanoflagellates by ciliates, and this is more plausible between January and April when relatively high ciliate abundance was detected (Fig. 3C).

In freshwater systems information about turnover rates due to protistan grazing on bacteria is relatively plentiful (Table 2). Higher turnover rates are found in eutrophic and hypereutrophic lakes, while lower turnover rates are found in oligotrophic lakes (Table 2). In marine environments, a relatively high turnover rate $(10 \%)$ due to flagellate grazing was also estimated in the eutrophic Savin Hill Cove embayment, USA (Epstein \& Shiaris 1992) (Table 2). Turnover rates in mesotrophic lakes are intermediate between those in oligotrophic and eutrophic lakes (Table 2) and the range and average values of turnover rates in the oligoto mesotrophic Uchiumi Bay are similar to those in mesotrophic lakes (Table 2). The results in the present study support those of previous studies: nanoflagellates are the main first link between bacteria and upper trophic levels, though ciliates may incidentally eat some bacteria. The present study also showed that the transfer of bacterial organic matter up the food web occurs mainly during spring and summer. Thus there appears to be seasonality in the use of bacteria by upper trophic levels. It is likely that ciliates are one of the main next trophic level organisms which consume nanoflagellates, although mezozooplankton will also play a role as predators of nanoflagellates (Lynn \& Montagnes 1991, Nakano et al. 2001). As information about grazing on bacteria by nanoflagellates and ciliates is still limited for marine systems, our data provide a valuable contribution towards understanding the structure and functioning of microbial food webs in coastal marine environments.

Acknowledgements. We thank K. Hyodo, T. Hirose and the staff of Uchiumi Institute of Oceanic and Fishery Science, and the students of Ehime University, for their help in field monitoring. Thanks also to Prof. Suzuki, Dr. T. Katano and other members of the Aquatic Biology and Ecology Laboratory of CMES, Ehime University, for their advice, discussions and encouragement throughout the study. We thank Drs. M. J. Morris and D. J. S. Montagnes for correction of our English and constructive comments on the manuscript. The present study was partly supported by the Grant-in-Aid for Scientific Research No. 12308027, JSPS, and the Research Fund of coastal environment in Uchiumi Bay, Uchiumi Village, Ehime Prefecture.

\section{LITERATURE CITED}

Albright LJ, Sherr EB, Sherr BF, Fallon RD (1987) Grazing of ciliated protozoa on free and particle-attached bacteria. Mar Ecol Prog Ser 38:125-129

Azam F, Fenchel T, Field J, Gray JS, Meyer-Reil LA, Thingstad F (1983) The role of water-column microbes in the sea. Mar Ecol Prog Ser 10:257-263

Bernard C, Rassoulzadegan F (1990) Bacteria or microflagellates as a major food source for marine ciliates: possible implications for the microzooplankton. Mar Ecol Prog Ser 64:147-155

Carlough LA, Meyer JL (1989) Protozoans in 2 southeastern blackwater rivers and their importance to trophic transfer. Limnol Oceanogr 34:163-177

Caron DA (1983) Technique for enumeration of heterotrophic and phototrophic nanoplankton, using epifluorescence microscopy, and comparison with other procedures. Appl Environ Microbiol 46:491-498

Caron DA, Finlay BJ (1994) Protozoan links in food webs. In: Hausmann K, Hulsmann N (eds) Progress in protozoology. Gustav Fisher Verlag, Stuttgart, p 125-130

Chihara M, Murano M (1997) An illustrated guide to marine plankton in Japan. Tokai University Press, Tokyo

Epstein SS, Shiaris MP (1992) Size-selective grazing of coastal bacterioplankton by natural assemblages of pigmented flagellates, colorless flagellates, and ciliates. Microb Ecol 23:211-225

Fenchel T (1980) Suspension feeding in ciliated protozoa: feeding rates and their ecological significance. Microb Ecol 6:13-25

Foissnner W (1994) Progress in taxonomy of planktonic freshwater ciliates. Mar Microb Food Webs 8:9-35

Fukami K, Meier B, Overbeck J (1991) Vertical and temporal changes in bacterial production and its consumption by heterotrophic nanoflagellates in a north German eutrophic lake. Arch Hydrobiol 122:129-145

Gonzalez JM, Sherr EB, Sherr BF (1990) Size-selective grazing on bacteria by natural assemblages of estuarine flagellates and ciliates. Appl Environ Microbiol 56:583-589

Granda A, Montagnes DJS (2003) An improved description of Strombidium sulcatum Claparède and Lachmann 1859 (Ciliophora) from slides of Fauré-Fremiet, and a designation of type material. J Eukaryot Microbiol 50:422-426

James MR, Hall JA, Barrett DP (1996) Grazing by protozoa in marine coastal and oceanic ecosystems off New Zealand. NZ Mar Freshw Res 30:313-324

Jonsson PR (1986) Particle size selection, feeding rates and growth dynamics of marine planktonic oligotrichous ciliates (Ciliophora: Oligotrichina). Mar Ecol Prog Ser 33: 265-277

Jürgens K, Stolpe G (1995) Seasonal dynamics of crustacean zooplankton, heterotrophic nanoflagelltes and bacteria in a shallow, eutrophic lake. Freshw Biol 33:27-38

Kisand V, Zingel P (2000) Dominance of ciliate grazing on bacteria during spring in a shallow eutrophic lake. Aquat Microb Ecol 22:135-142

Kivi K, Setälä O (1995) Simultaneous measurement of food particle selection and clearance rates of planktonic oligotrich ciliates (Ciliophora: Oligotrichina). Mar Ecol Prog Ser 119:125-137

Landry MR, Lehner-Fournier JM, Sundstrom JA, Fagerness VL, Selph KE (1991) Discrimination between living and heat-killed prey by a marine zooflagellate, Paraphysomonas vestita (Stokes). J Exp Mar Biol Ecol 146: 139-151

Lessard EJ, Swift E (1985) Species-specific grazing rates of 
heterotrophic dinoflagellates in oceanic waters, measured with a dual-label radioisotope technique. Mar Biol 87: 289-296

Lynn DH, Montagnes DJS (1991) Global production of heterotrophic marine planktonic ciliates. In: Reid PC (ed) Protozoa and their role in marine processes. NATO ASI Series, Vol G25. Springer-Verlag, New York, p 281-307

McManus GB, Fuhrman JA (1986) Bacterivory in seawater studies with the use of inert fluorescent particles. Limnol Oceanogr 31:420-426

McManus GB, Okubo A (1991) On the use of surrogate food particles to measure protistan ingestion. Limnol Oceanogr 36:613-617

Montagnes DJS, Lessard EJ (1999) Population dynamics of the marine planktonic ciliate Strombidinopsis multiauris: its potential to control phytoplankton blooms. Aquat Microb Ecol 20:167-181

Montagnes DJS, Taylor FJR, Lynn DH (1990) Strombidium inclinatum n. sp. and a reassessment of Strombidium sulcatum Claparede and Lachmann (Ciliophora). J Protozool 37:318-323

Moran R, Porath D (1980) Chlorophyll determination in intact tissues using N,N-dimethylformamide. Plant Physiol 65: $478-479$

Nakano S (1994) Estimation of phosphorus release rate by bacterivorous flagellates in Lake Biwa. Jpn J Limnol 55: 201-211

Nakano S, Ishii N, Manage PM, Kawabata Z (1998a) Trophic roles of heterotrophic nanoflagellates and ciliates among planktonic organisms in a hypereutrophic pond. Aquat Microb Ecol 16:153-161

Nakano S, Koitabashi, Ueda T (1998b) Seasonal changes in abundance of heterotrophic nanoflagellates and their consumption of bacteria in Lake Biwa with special reference to trophic interactions with Daphnia galeata. Arch Hydrobiol 142:21-34

Nakano S, Manage PM, Nishibe Y, Kawabata Z (2001) Trophic linkage among heterotrophic nanoflagellates, ciliates and metazoan zooplankton in a hypereutrophic pond. Aquat Microb Ecol 25:259-270

Porter KG, Feig YS (1980) The use of DAPI for identifying and counting aquatic microflora. Limnol Oceanogr 25:943-948

Rassoulzadegan F, Laval-Pento M, Sheldon RW (1988) Partitioning of the food ration of marine ciliates between picoand nanoplankton. Hydrobiologia 159:75-88

Rivier A, Brownlee DC, Sheldon RW, Rassoulzadegan F (1985) Growth of microzooplankton: a comparative study of bacterivorous zooflagellates and ciliates. Mar Microb Food Webs 1:51-60

Sanders RW, Porter KG, Bennett SJ, DE Biase AE (1989) Seasonal patterns of bacterivory by flagellates, ciliates, rotifers

Editorial responsibility: David A. Caron, Los Angeles, California, USA and cladocerans in a freshwater planktonic community. Limnol Oceanogr 34:673-687

Sherr BF, Sherr EB, Fallon RD (1987) Use of monodispersed, fluorescently labelled bacteria to estimate in situ protozoan bacterivory. Appl Environ Microbiol 53:958-965

Sherr BF, Sherr EB, Rassoulzadegan F (1988) Rates of digestion of bacteria by marine phagotrophic protozoa: temperature dependence. Appl Environ Microbiol 54:1091-1095

Sherr BF, Sherr EB, Pedros-Alio C (1989) Simultaneous measurement of bacterioplankton production and protozoan bacterivory in estuarine water. Mar Ecol Prog Ser 54:209-219

Šimek K, Straskrabova V (1992) Bacterioplankton production and protozoan bacterivory in a mesotrophic reservoir. J Plankton Res 14:773-787

Šimek K, Macek M, Seda J, Vyhnalek V (1990) Possible food chain relationships between bacterioplankton, protozoans and cladocerans in a reservoir. Int Rev Hydrobiol 75: 583-596

Šimek K, Bobkova K, Macek M, Nedoma J (1995) Ciliate grazing on picoplankton in a eutrophic reservoir during the summer phytoplankton maximum: A study at the species and community level. Limnol Oceanogr 40:1077-1090

Strom SL (2000) Bacterivory: interactions between bacteria and their grazers. In: Kirchman DL (ed) Microbial ecology of the oceans. Wiley-Liss, New York, p 351-386

Strüder-Kypke MC, Montagnes DJS (2002) Development of web-based guides to planktonic protists. Aquat Microb Ecol 27:203-207

Strüder-Kypke MC, Kypke ER, Agatha S, Warwick J, Montagnes DJS (2002) The user-friendly guide to coastal planktonic ciliate. Available at: www.liv.ac.uk/ciliate/site/ index.htm.

Tomaru Y, Kawabata Z, Nakano S (2000) Consumption of picoplankton by the bivalve larvae of Japanease pearl oyster Pinctada fucata martensii. Mar Ecol Prog Ser 192: 195-202

Tomaru Y, Udaka N, Kawabata Z, Nakano S (2002) Seasonal change of seston size distribution and phytoplankton composition in bivalve pearl oyster Pinctada fucata martensii culture farm. Hydrobiologia 481:181-185

Vaqué D, Pace ML (1992) Grazing on bacteria by flagellates and cladocerans in lakes of contrasting food-web structure. J Plankton Res 14:307-321

Vaqué D, Pace ML, Findlay SEG, Lints D (1992) Fate of bacterial production in a heterotrophic ecosystem: grazing by protists and metazoans in the Hudson estuary. Mar Ecol Prog Ser 89:155-163

Vaqué D, Gasol JM, Marrase C (1994) Grazing rates on bacteria: the significance of methodology and ecological factors. Mar Ecol Prog Ser 109:263-274

Submitted: January 1, 2005; Accepted: November 4, 2005 Proofs received from author(s): February 13, 2006 